\title{
Influence of Modern Hydro-Electric Power Development on the British Coal Trade.
}

\section{By Dr. Brysson Cunningham.}

TWHE striking, and even astonishing, development during recent years of sources of hydraulic power for the generation of electricity, gives rise to a pertinent and interesting inquiry as to the influence this widespread creation of hydroelectric energy is having, and is likely to have, upon the output and use of coal for power production. It is a question of not inconsiderable importance to Great Britain, since exportations of coal represent a very remunerative source of revenue to colliery proprietors and shipowners, while to the country as a whole, coal, as one of its most abundant and valuable mineral deposits, is a factor of the highest importance in its industrial activities.

As regards the internal economy of Great Britain, the available supplies of water power are of minor account : they are too insignificant to affect British coal consumption in any appreciable degree. It is in regard to countries abroad, Canada, Italy, Scandinavia, and Switzerland, for example, where extensive mountainous regions afford abundant scope for the realisation of hydraulic power, that the consideration chiefly applies, and Great Britain is concerned so far as their development affects the quantities of coal which are exported to customers abroad.

The fuel equivalent of one installed horse-power produced by water wheel, or turbine, has been computed by the Canadian Department of the Interior at $5 \frac{1}{2}$ tons of coal per annum. This figure is, of course, variable according to conditions of a widely differing character, and it involves several assumptions which are not of universal application, but it affords some idea of relative values and may conveniently and justifiably be used in general terms for a brief review of the subject. As a matter of fact, it is based on the average annual coal consumption per kilowatt-hour of all public utility power plants in the United States. This consumption has ranged, on a gradually decreasing scale, from $3 \mathrm{lb}$. of coal per kw.h. in 1920 to $1.69 \mathrm{lb}$. per kw.h. in 1929 the last-named figure being convertible into the $5 \frac{1}{2}$ tons of coal per annum adopted by the Canadian Government as its standard of comparison.

In the most recent report of the Dominion Water Power Bureau, dated Jan. 31, 1931, and reviewed in Nature of April 18, it was pointed out that, on this basis, the then existing water power installation in Canada of $6,125,012$ horse-power was capable of effecting a saving of nearly $33_{4}^{3}$ million tons of coal per annum. With the marked economies which are continually being realised in coal consumption in fuel power stations, the equivalent unit value indicated in the preceding paragraph is falling, but the saving of nearly 34 million tons of coal annually is no over-statement at the present time and is believed to be a conservative estimate.

This is for Canada only. If thereto be added the corresponding figures for all other countries in which water power development is in active prosecution, the aggregate arrived at will be of considerable magnitude, and if, furthermore, there be taken into account the potential supplies as yet undereloped, and, in most cases, greatly exceeding the capacity of the installations in actual operation, the grand total will be of dimensions which may well be described as colossal, and even startling. The United States Department of the Interior has recently issued a statistical statement, prepared by the Geological Survey, placing the world total of potential water horse-power at $447,000,000$, of which slightly more than 10 per cent is, as yet, actually developed. This estimate is by no means excessive: it is probably too low from lack of sufficient data. Previous articles in Nature have shown that there is more than forty million horsepower available in Canada and about twice as much in the United States ${ }^{1}$, while several European countries have resources estimated at from five to ten million horse-power each. ${ }^{2}$

At first sight, it might appear that such enormous actual and potential savings in fuel consumption for power producing purposes are bound to affect the coal trade very adversely and to bring about a substantial reduction in British coal exports. Yet, strange to say, this is not the case so far, and on investigation it will be found that the matter is not quite so simple a sum in subtraction as it would appear to be.

The figures in the table on p. 398 show the coal consumption in, and British exports of coal to, five leading countries during the past four years, with corresponding pre-War figures for 1913. From this statement it can be seen that, on the whole, there is remarkably little change in the situation as regards solid fuel consumption. Within not undue limits, the consumption of coal in Switzerland, Norway, Sweden, and Canada has remained approximately uniform and fairly equal to that of nearly twenty years ago. Italy, the one exception, has actually increased its coal consumption.

This unlooked-for and apparently incongruous result can be explained on several grounds, not the least valid of which is that, by reason of the natural expansion of the world's industrial activities and the increase in the amenities of civilisation, there is a corresponding augmentation in the demand for power, which affords scope for supply from sources other than fuel without diminishing the demand for the latter. Omitting other considerations, the rate of hydro-electric development in countries of stationary fuel consumption should be a measure of the natural expansion of industry, but owing to economies effected in fuel utilisation and in manufacturing processes and output, this cannot be claimed as a rigorous standard.

In considering the quantities of fuel consumed, notice should not be omitted of the increasing use of oil and natural gas as substitutes for coal. As yet, however, the gross consumption of such

$$
\text { No. 3227, VoL. 128] }
$$


alternatives for power-production purposes appears to be of insufficient proportions to affect the main trend of this inquiry. The Report of the Electricity Commissioners for the twelve months ended Mar. 31,1930 , shows that for a total of nearly twelve thousand million units of electricity generated at 568 stations in Great Britain, the quantity of fuel oil used was about 0.3 per cent of that of coal. In other countries the proportions will naturally vary according to circumstances. In the United States, for example, where supplies of oil are plentiful, the percentage of liquid fuel used for generating electricity in public utility power plants during 1929 was nearly ten times as great, that is about 3 per cent. These two representative cases show the most formidable competitor of Great Britain is Germany.. Before the War, 90. per cent of the coal imported into Italy was British. The percentage has since fallen to 55, while, owing to heavy deliveries of reparation coal, Germany now sends more than four times her pre-War quantity, representing 31 per cent of the total Italian imports of coal to-day.

Excluding the strike year, 1926, the annual coal output of Great Britain has not varied to any serious extent during the last ten years. In 1922, according to the Board of Trade returns, it was $249,606,864$ tons ; in 1930 it was $247,235,300$ tons. The highest year was 1923 with $276,000,560$ tons and the lowest, 1928, with $237,471,931$ tons. Ex-

Quantities of Coal Consumed in, and Exports of British Coal to, Italy, Switzerland, Norway, Sweden, and Canada.

(Metric Tons)

\begin{tabular}{|c|c|c|c|c|c|c|}
\hline \multicolumn{2}{|l|}{ Year. } & 1913. & 1927. & 1928. & 1929. & 1930. \\
\hline ItALX : & & & & & & \\
\hline Consumption & . & $10,643,126 \dagger$ & $12,884,712$ & $11,650,456$ & $13,267,652$ & $14,300,627^{*}$ \\
\hline $\begin{array}{l}\text { British Exports } \\
\text { SwITZERLAND : }\end{array}$ & .. & $9,804,737$ & $6,903,188$ & $6,730,499$ & $7,210,694$ & $7,284,405$ \\
\hline Consumption & & $1,969,454$ & $1,982,467$ & $1,908,154$ & $2,065,597$ & $1,985,868$ \\
\hline British Exports & & 30,358 & 129,244 & 127,262 & 137,324 & 127,180 \\
\hline $\begin{array}{l}\text { NoRWAX : } \\
\text { Consumption }\end{array}$ & . & & & & & \\
\hline $\begin{array}{l}\text { Consumption } \\
\text { British Exports }\end{array}$ & - & 2,27 & 2,24 & 2,1 & 2,434 & $2,274,514$ \\
\hline $\begin{array}{l}\text { British Expo } \\
\text { SwEDEN : }\end{array}$ & & $2,335,8$ & 1,599, & $1,135,348$ & 1,468 & $1,221,862$ \\
\hline Consumption & . & $5,241,786$ & $5,265,3$ & 4,45 & $5,389,127$ & $5,169,141^{*}$ \\
\hline $\begin{array}{l}\text { British Exports } \\
\text { CANADA }\end{array}$ & . & $4,637,609$ & $2,217,836$ & $1,564,903$ & $2,374,009$ & $1,795,364$ \\
\hline $\begin{array}{l}\text { CANADA : } \\
\text { Consumption } \ddagger \\
\text { British }\end{array}$ & . & $26,789,734$ & 28,794, & 27,723 & 28,401 & $25,802,449$ \\
\hline British Ex & . & 38,445 & 848 & 639,320 & 889 & 991,031 \\
\hline
\end{tabular}

that the influence of oil fuel is at present reasonably negligible and does not call for further examination.

Looking now at the British exportations of coal, it can be seen that, notwithstanding the uniformity of coal consumption, these exports have increased in relation to Canada, but have decreased very materially in relation to Norway and Sweden and less heavily in relation to Italy. Here some discrimination of explanation is necessary.

The decrease in coal exports to the last-named three countries is attributable mainly to foreign competition; particularly, in regard to Scandinavia; on the part of Poland, where the costs of production are much less than those of British coalfields, and where the rail haulage rate to the Baltic ports of Danzig and Gdynia is comparatively very cheap and the port and loading charges are on a lower scale than at British ports. ${ }^{3}$. As regards Italy, ports have shown a rather wider range, reaching $79,459,469$ tons in 1923 and falling to $50,055,118$ tons in 1928, the quantities for most of the years in the period lying between 50 and 60 million tons. ${ }^{4}$

The figures do not prove very much, one way or another. If there has been no progressive or ultimate increase, there has also been no appreciable decline of extended duration. Indeed, it has to be admitted that it is not possible to draw conclusions of a positive character from the official returns, and pending further evidence, the influence of current hydro-electric developments on the British coal industry must remain something of the nature of an interesting and elusive speculation.

1 Nature, April 18, 1931, and May 31, 1930.

2 NATURE, Sept. 6, 1930, gives figures for Italy and Switzerland at about the lower limit; France and Norway reach the higher.

3 Report of British Coal Delegation to Sweden, Norway, and Denmark. H.M. Stationery Office, October 1930.

4 Board of Trade Annual Journal, and Chamber of Shipping Annual Report, 1930-31.

\section{Periodic Phýsico-Chemical Phenomena.}

By Dr. ERnest S. HedGes.

$\mathrm{P}$ ERIODIC phenomena of all types have a peculiar fascination to the human mind, possibly because they suggest some of the processes of life. On the largest scale, mechanical periodicity is inherent in the movements of celestial bodies and of the earth, producing secondary periodicities; which we recognise as the yearly seasons, alternating day and night, the ebb and flow of the tides, and in other ways. These time-periodicities in their turn leave their mark on earthly structures which are in the course of formation, producing spatial periodicities, such as the annual rings in the

No. 3227, VoL. 128] 